\title{
Pengelolaan Limbah Alat Pelindung Diri (APD) di Daerah Jakarta Barat Berbasis Smart Infectious Waste Bank (SIWAB)
}

\author{
Intan Rahmalia, Namira Yostya Oktiviani, Fifik Samhun Kahalnashiri, Nova Ulhasanah*, \\ I Wayan Koko Suryawan
}

Jurusan Teknik Lingkungan, Fakultas Perencanaan Infrastruktur, Universitas Pertamina.

\begin{abstract}
ABSTRAK
Pandemi COVID-19 yang melanda dunia mengharuskan masyarakat untuk melindungi diri dari penularan penyakit melalui penggunaan alat pelindung diri (APD). APD dari COVID-19 seperti masker bedah (surgery mask), sarung tangan, pakaian dekontaminasi (hazardous material suit), dan pelindung wajah (face shield) sebagian besar terbuat dari plastik dan kebutuhannya meningkat tajam. Namun, limbah APD tidak dipahami masyarakat sebagai limbah B3 infeksius sehingga sering dicampur pembuangannya bersama dengan limbah domestik. Kondisi tersebut dapat ditemukan pada seluruh lokasi di Indonesia, terutama Daerah Khusus Ibukota (DKI) Jakarta. Berdasarkan laporan Dinas Lingkungan Hidup DKI Jakarta, penghasil limbah APD domestik tertinggi berada di daerah Jakarta Barat. Melalui penelitian dilakukan pengelolaan limbah APD di daerah Jakarta Barat berbasis Smart Infectious Waste Bank (SIWAB). Penelitian ini bertujuan untuk memperoleh timbulan limbah APD yang berasal dari rumah tangga dan merancang bank sampah yang didukung oleh teknologi digital (aplikasi) sebagai sarana pengelolaan limbah APD. Penelitian diawali dengan studi pendahuluan timbulan limbah APD beserta karakteristiknya dan dilanjutkan dengan perancangan SIWAB. Hasil penelitian berupa aplikasi SIWAB yang terintegrasi dengan smartphone. Penelitian ini akan memberikan kontribusi besar kepada pemerintah Jakarta Barat dalam pengelolaan limbah B3 infeksius khususnya dan Indonesia umumnya.
\end{abstract}

Kata kunci: APD, COVID-19, Limbah B3 Infeksius, Limbah Domestik, SIWAB

\begin{abstract}
The COVID-19 pandemic that surge the world, requires people to protect themselves from the transmission of disease by using Personal Protective Equipment (PPE). The COVID-19 PPE, such as surgery masks, gloves, hazardous material suits, and face shields, are mostly made of plastic and the need for procurement is increasing. However, the community does not understand the PPE waste as infectious hazardous waste, so often it mixed with domestic waste. This condition can be found in all regions of Indonesia, especially the Special Capital Region of Jakarta. Based on a report from the Jakarta Environment Agency, the highest producer of domestic PPE waste is in the West Jakarta. Through this research, PPE waste management was carried out in the West Jakarta area based on the smart infectious waste bank (SIWAB). This study aims to obtain PPE waste generation from household and to design a waste bank that is supported by digital technology (application) as a means of PPE waste management. The research begins with a preliminary study of the generation of PPE waste and its characteristics and next designing an SIWAB application. The research result is a SIWAB application that is integrated with smartphone. This research will make a major contribution to the West Jakarta government in managing Toxic and Hazardous Materials (THM) infectious waste and Indonesia in general.
\end{abstract}

Keywords: PPE, COVID-19, THM Infectious waste, Domestic Waste, SIWAB

Citation: Rahmalia, I., Oktiviani, N. Y., Kahalnashiri, F. S., Ulhasanah, N., Suryawan, I. W. K. (2022). Pengelolaan Limbah Alat Pelindung Diri (APD) di Daerah Jakarta Barat Berbasis Smart Infectious Waste Bank (SIWAB). Jurnal Ilmu Lingkungan, 20(1), 91-101, doi:10.14710/jil.20.1.91-101

\section{Latar Belakang}

Pandemik COVID-19 yang melanda dunia menyebabkan pemerintah Indonesia menyatakan status bencana nasional terhadap Indonesia yang ditulis dalam Keputusan Presiden Republik Indonesia No. 12 Tahun 2020. Dengan adanya keputusan tersebut seluruh masyarakat diwajibkan untuk melindungi diri dari penularan penyakit melalui penggunaan Alat
Pelindung Diri (APD). Penggunaan APD seperti masker medis, sarung tangan, pelindung wajah, kacamata googles dan baju dekontaminasi diprioritaskan bagi tenaga medis utamanya, namun masyarakat dianjurkan pula untuk melakukan upaya perlindungan maksimal di masa pandemik. Kementerian Kesehatan Republik Indonesia (2020) menyatakan bahwa dalam penggunaan APD, masyarakat belum memahami mengenai limbahnya yang termasuk dalam kategori

\footnotetext{
*Penulis korespondensi: nova.u@universitaspertamina.ac.id, novaulhasanah@gmail.com
} 
limbah B3, sehingga limbah APD domestik cenderung dibuang bersama limbah domestik lainnya tanpa dipotong dan diberikan desinfeksi terlebih dahulu.

Limbah APD dikategorikan sebagai limbah B3 karena terkandungnya komponen berbahaya pada objek tersebut. Masker bedah dengan 3 lapisan (3-Ply Surgical Mask) adalah masker bedah yang umum digunakan masyarakat pada masa pandemik COVID-19 untuk membatasi penetrasi pada partikel maupun patogen pada kedua arah. Lapisan tengah pada masker berfungsi untuk menyaring lebih dari 95\% virus dan lebih dari $98 \%$ bakteri pada arah luar maupun dalam masker (Lee, 2020). Terkandungnya patogen pada lapisan tengah masker, yaitu lapisan filter, menyebabkan objek ini dikategorikan sebagai bahan berbahaya dan beracun (B3) dengan karakteristik infeksius menurut PP. No. 101 Tahun 2014. Di samping itu, pelindung wajah termasuk dalam jenis APD yang bersifat beberapa kali pakai (reusable item) yang perlu diberikan perlakuan desinfeksi setelah pemakaiannya (Wain, 2020). Apabila desinfeksi tidak dilakukan, maka pelindung wajah akan mengandung patogen yang berasal dari tetesan saliva pasien COVID-19 dan dikategorikan sebagai limbah infeksius. Pada masa pandemik COVID-19, sarung tangan plastik sekali pakai (disposable glove) dan baju dekontaminasi digunakan oleh masyarakat sebagai APD dalam mencegah paparan kontak langsung pada objek yang berada di area umum. Hal ini dilakukan untuk meningkatkan standar proteksi kesehatan dari paparan patogen terhadap keseluruhan tubuh.

Dinas Lingkungan Hidup DKI Jakarta menyatakan bahwa Jakarta Barat merupakan daerah penyumbang limbah APD terbesar di wilayah DKI Jakarta dengan timbulan yang dihasilkan sebesar 191,38 kilogram (Detik, 2020). Hal tersebut didasari bahwa Kota Jakarta Barat memiliki jumlah penduduk terbanyak kedua setelah Jakarta Timur, yaitu sebanyak 2.589.933 jiwa di tahun 2019, namun wilayah ini memiliki kepadatan penduduk tertinggi di DKI Jakarta yaitu sebesar 20.813 jiwa $/ \mathrm{km}^{2}$ (BPS, 2020). Dampak yang ditimbulkan dari pembuangan limbah B3 infeksius secara tidak tepat akan menyebabkan masalah lingkungan dan kesehatan. Penyakit yang disebabkan dari paparan patogen seperti virus atau bakteri dapat terjadi melalui media air, tanah, dan udara (Ruslinda, 2018). Dalam mencegah dampak yang ditimbulkan akibat pembuangan limbah B3 tersebut, Kementerian Lingkungan Hidup dan Kehutanan mengeluarkan Surat Edaran No. SE.2/MENLHK/PSLB3/PLB.3/3/2020 tentang Pengelolaan Limbah Infeksius (Limbah B3) dan Sampah Rumah Tangga dari Penanganan Corona Virus Disease (COVID-19). Selain itu, Kementerian Kesehatan RI mengeluarkan buku Pedoman Pengelolaan Rumah Sakit Rujukan, Rumah Sakit Darurat, dan Puskesmas yang Menangani Pasien COVID-19 untuk menjelaskan panduan tata cara untuk mengelola limbah APD domestik.
Wilayah Jakarta Barat memiliki jumlah bank sampah terbesar di DKI Jakarta yaitu sejumlah 782 bank sampah (Jakarta Smart City, 2020). Salah satu bank sampah induk di wilayah Jakarta Barat adalah Bank Sampah Induk Sehati yang berada di Kecamatan Cengkareng (Pemerintah Kota Administrasi Jakarta Barat, 2020). Bank Sampah Induk Sehati menerima limbah padat domestik tipe anorganik yang meliputi sampah kaca, logam (metal), kertas, dan plastik yang berasal 8 kecamatan di Jakarta Barat dengan timbulan 0,5 kg/orang/hari (Noviyanti, 2019). Hal tersebut mengindikasikan bahwa belum terdapatnya bank sampah di Jakarta Barat yang menyediakan pelayanan pengelolaan limbah infeksius dari masyarakat, seperti limbah APD.

Perihal tidak adanya pengelola limbah B3 infeksius yang tersedia di wilayah Jakarta Barat, maka penelitian ini bertujuan untuk merancang bank sampah secara tepat guna yang mampu mengelola limbah B3 infeksius berupa limbah APD domestic dan untuk mengetahui karakteristik dan jumlah timbulan sampah limbah APD di daerah Jakarta Barat. Dorongan keprihatinan kondisi lingkungan dari timbulan limbah APD serta adanya peluang manfaat yang diperoleh masyarakat secara langsung, mampu memberikan peluang baik dari pengadaan bank sampah infeksius tersebut. Bank sampah infeksius atau Smart Waste Infectious Bank (SIWAB) akan mengangkut limbah APD dari setiap rumah nasabah sekaligus mengedukasi masyarakat mengenai limbah APD dan keterkaitannya sebagai limbah B3 infeksius. Hal tersebut akan mendukung praktik 3M (menggunakan masker, mencuci tangan, dan menjaga jarak) yang dikampanyekan oleh pemerintah Indonesia dalam memutus mata rantai penularan COVID-19 di Indonesia. SIWAB adalah bank sampah yang terintegrasi dengan smartphone sehingga memudahkan pengguna dalam menabung sekaligus mengelola sampah secara praktis. Konsep pemeliharaan lingkungan, peningkatkan kualitas kesehatan, dan peningkatkan kesejahteraan masyarakat menjadi prinsip utama SIWAB. Dengan adanya SIWAB diharapkan dapat membantu pemerintah dalam mengelola limbah APD yang dihasilkan dari kegiatan domestik secara berkelanjutan dan lestari, mengelola limbah B3 infeksius secara aman di masa pandemik, mudah diterapkan oleh berbagai kalangan masyarakat, dan mewujudkan program pemerintah dalam penguatan kembali keberadaan bank sampah yang memiliki potensi besar dalam reduksi jumlah timbulan limbah yang sampai di TPA dan peningkatan pendayagunaan masyarakat setempat.

\section{Metodologi}

Data primer adalah data yang didapatkan dari sumber pertama baik melalui perseorangan ataupun kelompok yang dilakukan melalui wawancara atau pengisian kuisioner (Umar, 2008). Metode pengumpulan data primer secara langsung atau 
wawancara dilakukan dengan memberikan pertanyaan secara terstruktur yang telah ditentukan tanpa menyesuaikan kondisi pada saat wawancara agar mendapatkan hasil penilaian interpretif dari responden mengenai topik penelitian yang dibahas (Bastian, 2018). Sementara metode pengumpulan data primer secara tidak langsung dilakukan melalui penyebaran kuisioner secara acak dan disampaikan dalam pertanyaan tertutup bersama pilihan jawaban yang disediakan oleh peneliti sesuai dengan variabel penelitian (Widoyoko, 2016).

Dalam penelitian ini, dilakukan metode wawancara secara langsung melalui panggilan video (video call) bersama responden ahli. Wawancara yang dilakukan melalui video call dilakukan dengan pertimbangan bahwa adanya pembatasan sosial berskala besar (PSBB) di masa pandemik COVID-19. Di samping itu, dilakukan wawancara secara tidak langsung melalui penyebaran kuisioner secara daring kepada target responden penelitian ini. Penentuan ukuran sampel pada pengumpulan data primer dilakukan dengan pendekatan statistik distribusi normal dengan diterapkan batas minimum sampel sebanyak 30 subjek dengan kendali ketat pada sampel yang berukuran 10 sampai 20 subjek sebagaimana yang dianjurkan oleh Alwi (2016) pada eksperimen sederhana. Data sekunder adalah data yang berasal dari sumber tidak langsung seperti dokumen-dokumen yang dapat memberikan data pendukung dalam pengolahan data primer dalam karya tulis (Sugiyono, 2012). Dalam penelitian ini digunakan data sekunder relevan yang berasal dari unggahan pada laman instansi pemerintah, jurnal ilmiah, dan buku yang diunggah secara daring.

Metode pengolahan data yang digunakan untuk mendukung penelitian ini adalah perhitungan timbulan sampah yang didasarkan pada proyeksi penduduk tahun 2020, uji validitas dan uji reliabilitas. Metode perhitungan volume limbah APD yang digunakan dalam penelitian ini (WIKA, 2020) terdapat pada persamaan 1 .

Jumlah volume limbah $(\mathrm{kg})=$

Proyeksi jumlah penduduk pada tahun 2020 (jiwa) $\mathbf{x}$ Asumsi penduduk yang beraktivitas di luar rumah (30\%) x Massa limbah APD (kg)

Validitas merupakan skala yang digunakan untuk melakukan pengukuran seharusnya dengan infersi yang didapatkan mendekati kebenaran atau valid. Uji validitas digunakan untuk mengetahui kebenaran data yang didapatkan dalam penelitian ini, sehingga mampu menjadi penguat dalam pengambilan kesimpulan yang didapatkan dari hasil penelitian (Sarwono, 2011). Untuk melakukan uji validitas digunakan persamaan 2 .

$$
r_{x y}=\frac{N\left(\sum x_{i} y_{i}\right)-\left(\sum x_{i}\right)\left(\sum y_{i}\right)}{\sqrt{N\left(\left(\sum x_{i}^{2}\right)-\left(\sum x_{i}\right)^{2}\right)-\left(N\left(\sum y_{i}^{2}\right)-\left(y_{i}\right)^{2}\right)}}
$$

Keterangan:

$\mathrm{r}_{\mathrm{xy}}=$ Validitas instrumen

$\mathrm{x}=$ Skor yang diperoleh subyek dari seluruh item

$\mathrm{y}=$ Skor total yang diperoleh dari seluruh item

$\Sigma \mathrm{x}=$ Jumlah skor distribusi $\mathrm{X}$

$\Sigma \mathrm{y}=$ Jumlah skor distribusi $\mathrm{Y}$

(Yusup, 2018)

Dengan menggunakan Persamaan 2., didapatkan hasil pengujian validitas data pada Tabel 1 . Uji reliabilitas merupakan suatu nilai hasil pengukuran yang konsisten pada setiap pengukuran yang sama dengan nilai stabilitas yang sama. Uji reliabilitas digunakan untuk mengetahui tingkat kepercayaan data yang didapatkan dari penyebaran kuesioner, sehingga apabila data yang didapatkan reliabel atau terpercaya maka dapat digunakan untuk pengambilan kesimpulan dari hasil penelitian (Sarwono, 2011). Uji reliabilitas dapat dihitung dengan persamaan 3 .

Tabel 1. Rekapitulasi Hasil Uji Validitas Data

\begin{tabular}{|c|c|c|c|}
\hline No. & Variabel & " Nilai Validitas & Keterangan \\
\hline 1 & $\begin{array}{l}\text { Berapa lembar (piece) APD dengan } \\
\text { jenis satu kali pakai (contoh: masker } \\
\text { bedah dan sarung tangan plastik) } \\
\text { yang anda gunakan dalam satu hari? }\end{array}$ & 0,597 & $\begin{array}{l}\text { Data pada variabel } 1 \text { adalah valid unutk digunakan, karena } \\
\text { nilai } r \text { hitung }>\text { nilai } r \text { produk yakni dengan nilai } 0,597>0,325\end{array}$ \\
\hline 2 & $\begin{array}{l}\text { Berapa lembar masker bedah } \\
\text { (surgery mask) yang anda beli dalam } \\
\text { satu bulan? }\end{array}$ & 0,811 & $\begin{array}{l}\text { Data pada variabel } 2 \text { adalah valid untuk digunakan, karena } \\
\text { nilai } r \text { hitung }>\text { nilai } r \text { produk yakni dengan nilai 0,811 >0,325. }\end{array}$ \\
\hline 3 & $\begin{array}{l}\text { Berapa banyak sarung tangan plastik } \\
\text { yang anda beli dalam satu bulan? }\end{array}$ & 0,642 & $\begin{array}{l}\text { Data pada variabel } 3 \text { adalah valid untuk digunakan, karena } \\
\text { nilai } r \text { hitung }>\text { nilai } r \text { produk yakni dengan nilai } 0,642>0,325 \text {. }\end{array}$ \\
\hline 4 & $\begin{array}{c}\text { Berapa banyak pakaian } \\
\text { dekontaminasi (hazardous material } \\
\text { suit) yang anda beli dalam satu } \\
\text { bulan? }\end{array}$ & 0,325 & $\begin{array}{c}\text { Data pada variabel } 3 \text { adalah tidak valid untuk digunakan, } \\
\text { karena nilai } r \text { hitung }>\text { nilai } r \text { produk yakni dengan nilai } 0 \text { > } \\
0,325 \text {. }\end{array}$ \\
\hline 5 & $\begin{array}{l}\text { Berapa banyak pelindung wajah ( face } \\
\text { shield) yang anda beli dalam satu } \\
\text { bulan? }\end{array}$ & 0 & $\begin{array}{l}\text { Data pada variabel } 3 \text { adalah valid untuk digunakan, karena } \\
\text { nilai } r \text { hitung }>\text { nilai r produk yakni dengan nilai } 0.357>0.325 \text {. }\end{array}$ \\
\hline
\end{tabular}


Tabel 2. Rekapitulasi Hasil Uji Reliabilitas Data

\begin{tabular}{|c|c|}
\hline $\begin{array}{c}\text { Nilai } \\
\text { Reabilitas }\end{array}$ & Keterangan \\
\hline 0,597 & $\begin{array}{l}\text { Pengujian reliabilitas pada hasil data pengisian kuisioner oleh } 38 \text { responden menghasilkan nilai } \mathrm{r} \text { hitung }>\mathrm{r} \text { produk yakni } \\
\text { sebesar } 0,7679>0,334 \text {. Sehingga, data yang didapatkan adalah terpercaya untuk digunakan penelitian. }\end{array}$ \\
\hline
\end{tabular}

Tabel 3. Distribusi Pengguna Alat Pelindung Diri (APD) Menurut Pekerjaan Responden

\begin{tabular}{lccccc}
\hline \hline \multirow{2}{*}{ Pekerjaan } & \multirow{2}{*}{$\begin{array}{c}\text { Jumlah } \\
\text { Responden }\end{array}$} & Masker & Sarung Tangan & Pelindung Wajah & Benggunaan APD (unit/hari) \\
\cline { 3 - 6 } & 32 & 57 & 3 & 10 & 2 \\
Mahasiswa & 3 & 6 & 0 & 0 & 1 \\
Wiraswasta & 3 & 2 & 1 & 0 & 0 \\
\hline
\end{tabular}

Sumber: Hasil Survei Data di Melalui Kuisioner Penelitian 2020

$$
r_{1}=\left(\frac{k}{k-1}\right)\left(1-\frac{\sum \sigma_{b}^{2}}{\sigma_{1}}\right)
$$

Keterangan:

$r_{1}=$ Reliabilitas instrumen

$\mathrm{k}$ = Banyaknya butir pertanyaan

$\Sigma_{\mathrm{b}^{2}}=$ Jumlah varians butir

$\sigma_{\mathrm{t}^{2}}=$ Varians soal

(Yusup, 2018)

Dengan menggunakan Persamaan 3., didapatkan hasil dari pengujian reliabilitas data pada Tabel 2 .

\section{Hasil dan Pembahasan}

\subsection{Timbulan dan Komposisi Limbah APD}

Penelitian ini bertujuan untuk menganalisis perilaku masyarakat Jakarta Barat dalam mengelola limbah APD dan menentukan karakteristik serta timbulan limbah APD dari sampel yang ditentukan. Menurut hasil survei dan wawancara yang dilakukan, didapatkan representasi data jumlah timbulan limbah APD di kawasan Jakarta Barat berdasarkan pemakaiannya dalam satu hari maupun satu bulan. Penggunaan alat pelindung diri (APD) berjenis satu kali pakai (disposable item) yang dikaji dalam penelitian ini yaitu masker bedah (surgery mask) dan sarung tangan plastik. Sementara, APD beberapa kali pakai (reusable item) yang dikaji dalam penelitian ini yaitu baju dekontaminasi (hazardous material suit) dan pelindung wajah (face shiled).

Dalam survei dan wawancara yang dilakukan, responden memberikan informasi mengenai jumlah alat pelindung diri (APD) yang digunakan dalam satu hari. Sebagian besar responden penelitian memiliki pekerjaan sebagai wiraswasta dan mahasiswa yang rutin beraktivitas di luar rumah atau memiliki intensitas tinggi berada di kerumunan umum, sehingga pemakaian masker bedah dengan face shield menjadi prioritas dalam berkegiatan.

Selain itu, berdasarkan hasil survei dan wawancara, tidak ditemukan responden dari setiap kecamatan yang menggunakan baju dekontaminasi sebagai alat pelindung diri (APD) di masa pandemik COVID-19. Hal tersebut dijelaskan dalam Tabel 1, di mana responden yang memiliki pekerjaan sebagai mahasiswa dan wiraswasta mampu menggunakan 63 lembar masker dalam satu hari. Sementara ibu rumah tangga menghasilkan timbulan limbah APD yang lebih rendah dibandingkan pekerjaan lainnya karena kegiatan yang didominasi di dalam rumah. Penggunaan sarung tangan plastik dilakukan pada saat responden yang melakukan aktivitas berbelanja di pasar swalayan maupun pasar tradisional. Selain itu, berdasarkan hasil survei dan wawancara, tidak ditemukan responden untuk setiap kecamatan yang menggunakan baju dekontaminasi sebagai alat pelindung diri (APD) di masa pandemik COVID-19.

Timbulan limbah APD bervariasi untuk setiap kecamatan di Kota Jakarta Barat sebagaimana yang diitunjukkan dalam Tabel 4. Limbah APD yang memiliki nilai timbulan tertinggi di kawasan Jakarta Barat, yaitu limbah masker dengan jumlah sebesar 188,224 kg. Kecamatan Kembangan menghasilkan komposisi limbah masker dan sarung tangan tertinggi dari kawasan Jakarta Barat, yaitu 28\% dan 65\%. Sementara Kecamatan Palmerah menghasilkan komposisi limbah pelindung wajah (face shield) tertinggi dari seluruh kecamatan di Jakarta Barat, yaitu sebesar 28\%. Kecamatan Kalideres, Grogol Petamburan, Cengkareng, Taman Sari, dan Tambora tidak memiliki timbulan limbah sarung tangan plastik. Di samping itu, seluruh kecamatan di Jakarta Barat tidak menghasilkan timbulan limbah baju dekontaminasi.

Berdasarkan hasil survei dan wawancara, didapatkan informasi mengenai kebiasaan masyarakat Jakarta Barat dalam menangani limbah APD. Berdasarkan Gambar 1 dan Tabel 3, terdapat 55\% responden dari delapan kecamatan di Jakarta Barat melakukan pola pembuangan limbah APD dengan cara mencampurkannya bersama sampah lain dalam satu tempat sampah. Pola perilaku tersebut mengindikasikan bahwa masyarakat belum memahami sifat dan karakteristik limbah APD sebagai limbah B3 infeksius. 
Tabel 4. Timbulan Limbah Alat Pelindung Diri (APD) di Jakarta Barat

\begin{tabular}{|c|c|c|c|c|c|c|c|c|c|}
\hline \multirow[b]{2}{*}{ Kecamatan } & \multirow{2}{*}{$\begin{array}{c}\text { Jumlah } \\
\text { KK } \\
\text { (N) }\end{array}$} & \multicolumn{4}{|c|}{ Timbulan Limbah APD (kg/bulan) } & \multicolumn{4}{|c|}{ Komposisi Limbah APD (\%) } \\
\hline & & Masker & $\begin{array}{l}\text { Sarung } \\
\text { Tangan }\end{array}$ & Hazmat & $\begin{array}{c}\text { Pelindung } \\
\text { Wajah }\end{array}$ & Masker & $\begin{array}{l}\text { Sarung } \\
\text { Tangan }\end{array}$ & Hazmat & $\begin{array}{c}\text { Pelindung } \\
\text { Wajah }\end{array}$ \\
\hline Palmerah & 11 & 46,8 & 0,0035 & 0 & 1,5587 & 25 & 3 & 0 & 28 \\
\hline Kebun Jeruk & 9 & 52 & 0,0385 & 0 & 0,8502 & 28 & 32 & 0 & 15 \\
\hline Kalideres & 1 & 0 & 0 & 0 & 0,2834 & 0 & 0 & 0 & 5 \\
\hline $\begin{array}{l}\text { Grogol } \\
\text { Petamburan }\end{array}$ & 5 & 18,72 & 0 & 0 & 0,5668 & 10 & 0 & 0 & 10 \\
\hline Cengkareng & 1 & 4,68 & 0 & 0 & 0,4251 & 2 & 0 & 0 & 8 \\
\hline Kembangan & 8 & 55 & 0,077 & 0 & 1,5 & 29 & 65 & 0 & 27 \\
\hline Taman Sari & 1 & 7,8 & 0 & 0 & 0,1417 & 4 & 0 & 0 & 3 \\
\hline Tambora & 2 & 3,74 & 0 & 0 & 0,2 & 2 & 0 & 0 & 4 \\
\hline \multicolumn{2}{|c|}{ Total (kg/bulan) } & 188,74 & 0,119 & $\mathbf{0}$ & 5,529 & $100 \%$ & $100 \%$ & $0 \%$ & $100 \%$ \\
\hline \multicolumn{3}{|c|}{$\begin{array}{l}\text { Total Limbah APD Sekali Pakai } \\
\text { (kg/bulan)* }\end{array}$} & & \multicolumn{2}{|l|}{188,85} & \multicolumn{4}{|c|}{$97,15 \%$} \\
\hline \multicolumn{3}{|c|}{$\begin{array}{l}\text { Total Limbah APD Beberapa } \\
\text { Kali Pakai (kg/bulan)** }\end{array}$} & & \multicolumn{2}{|l|}{5,529} & \multicolumn{4}{|c|}{$2,85 \%$} \\
\hline
\end{tabular}

Catatan:

*Limbah APD Sekali Pakai Terdiri Dari Masker dan Sarung Tangan

** Limbah APD Beberapa Kali Pakai Terdiri Dari Hazmat dan Pelindung Wajah

Sumber: Hasil Survei Data di Melalui Kuisioner Penelitian 2020 dan Hasil Pengolahan Data Penelitian 2021

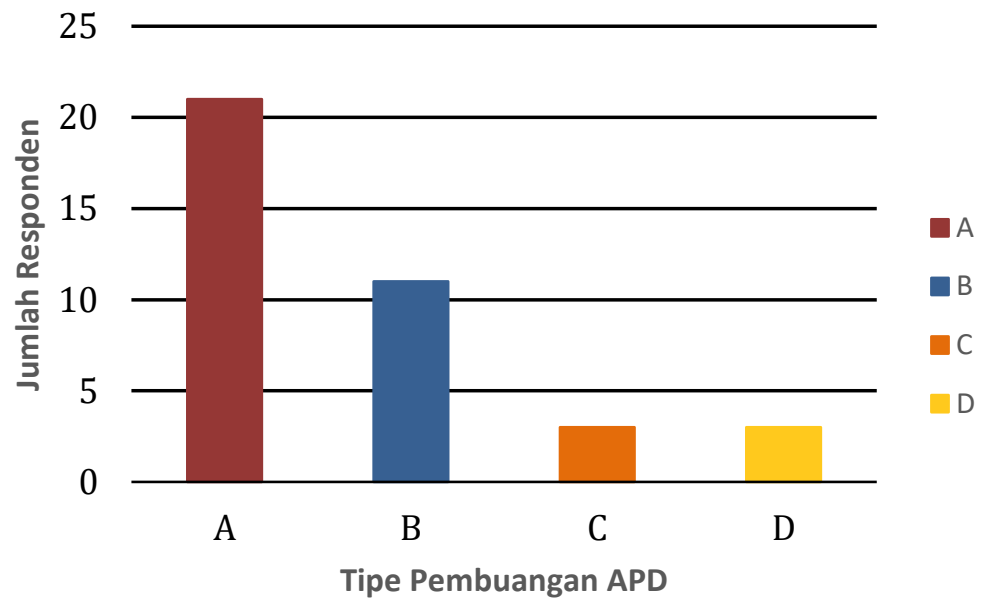

Gambar 1. Grafik Pola Penanganan Limbah APD oleh Masyarakat Jakarta Barat Sumber: Hasil Survei Data di Melalui Kuisioner Penelitian 2020

Tabel 5. Keterangan Pola Penanganan Limbah APD oleh Masyarakat Jakarta Barat

\begin{tabular}{clcc}
\hline \hline & \multicolumn{1}{c}{ Keterangan } & $\begin{array}{c}\text { Jumlah } \\
\text { Responden } \\
\text { (N) }\end{array}$ & Persentase (\%) \\
\hline A & $\begin{array}{l}\text { Limbah APD dibuang di tempat sampah bersama sampah lain } \\
\text { B } \quad \begin{array}{l}\text { Limbah APD dibuang di tempat sampah bersama sampah lain, namun dilakukan } \\
\text { desinfeksi atau penyemprotan zat anti-virus }\end{array}\end{array}$ & 21 & 55 \\
C $\quad \begin{array}{l}\text { Limbah APD dibuang pada wadah terpisah yang telah dipisahkan antara sampah } \\
\text { APD COVID-19 dengan sampah lainnya }\end{array}$ & 3 & 29 \\
$\quad \begin{array}{l}\text { Limbah APD dibuang pada wadah terpisah yang telah dipisahkan antara sampah } \\
\text { APD COVID-19 dengan sampah lainnya, serta dilakukan desinfeksi pada sampah } \\
\text { COVID-19 tersebut }\end{array}$ & 3 & 8 \\
\hline Sumber: Hasil Survei Data di Melalui Kuisioner Penelitian 2020 & & 8 \\
\hline
\end{tabular}

Sumber: Hasil Survei Data di Melalui Kuisioner Penelitian 2020

Limbah B3 infeksius yang tercampur dengan limbah domestik dapat menimbulkan pencemaran lingkungan hidup dan kesulitan dalam pengolahan selanjutnya (Iswanto, Sudarmadji, Wahyuni, \& Sutomo, 2016). Selain itu, 29\% responden telah cukup memahami penanganan limbah APD secara tepat dengan melakukan desinfeksi sebelum mencampurkannya bersama sampah domestik lain.
Berdasarkan hasil survei atau wawancara tersebut dapat diketahui bahwa $55 \%$ responden perlu diberikan pemahaman yang sederhana dan mudah dimengerti mengenai limbah B3 infeksius, sehingga dalam hal ini perlu dilakukan upaya pengedukasian yang tepat agar lingkungan hidup tetap terjaga dari ancaman kerusakan dan keutamaan peningkatan kualitas kesehatan masyarakat (Setiyono, 2001). 


\section{- $\quad$ Timbulan Limbah APD}

Dalam rangka mengetahui jumlah timbulan limbah APD di DKI Jakarta dibutuhkan data jumlah penduduk, massa dari tiap timbulan limbah APD, dan durasi penimbunan limbah APD. Data proyeksi jumlah penduduk DKI Jakarta yang digunakan sebagai perhitungan adalah data pada tahun 2020, yaitu sebesar 10.644.986 jiwa dengan jumlah penduduk Jakarta Barat 2.619.785 jiwa (BPS, 2015). Massa untuk tiap limbah APD berupa masker bedah, sarung tangan plastik, pelindung wajah (face shield), dan baju dekontaminasi (hazardous material suit) berturutturut adalah sebesar $0,156 \mathrm{~kg}, 0,0007 \mathrm{~kg}, 0,1417 \mathrm{~kg}$, dan 2,721 kg (Amazon, 2020).

Dilakukan perhitungan timbulan limbah APD berdasarkan pengolahan data literatur dan hasil data observasi. Perhitungan dilakukan untuk menentukan besar timbulan sesungguhnya dan mengetahui perbedaan yang didapatkan bedasarkan perhitungan timbulan limbah APD secara teori dan eksperimen.

1. Perhitungan secara literatur adalah perhitungan timbulan sampah yang didasarkan pada proyeksi penduduk tahun 2020 untuk Provinsi DKI Jakarta dan Jakarta Barat dengan menggunakan metode perhitungan dan asumsi menurut literatur. Pada Tabel 6 didapatkan hasil perhitungan volume limbah APD yang dihasilkan oleh wilayah Jakarta Barat dan DKI Jakarta.

Berdasarkan perhitungan volume sampah tersebut, ditentukan besaran timbulan limbah APD untuk setiap orang dalam satu hari. Besar timbulan limbah APD masker bedah, sarung tangan, pelindung wajah, dan baju dekontaminasi secara berturut-turut baik untuk wilayah DKI Jakarta ataupun wilayah Jakarta Barat memiliki nilai yang sama secara teori, yaitu sebesar 0,00153 kg/orang/hari, 0,0000069 $\mathrm{kg} /$ orang/hari, $\quad 0,00141$ $\mathrm{kg} /$ orang/hari, dan 0,027 kg/orang/hari. Oleh karena itu, timbulan limbah APD di DKI Jakarta ataupun Jakarta Barat adalah sebesar 0,030 $\mathrm{kg} /$ orang/hari dan besar kontribusi volume limbah APD di wilayah Jakarta Barat terhadap keseluruhan volume limbah APD di DKI Jakarta secara teori adalah 24,61\%.

Tabel 6. Volume Sampah di Jakarta Barat dan DKI Jakarta Menurut Literatur

\begin{tabular}{lll}
\hline \multirow{2}{*}{ Jenis Limbah APD } & \multicolumn{2}{c}{ Jumlah Timbulan per Bulan } \\
& \multicolumn{2}{c}{ (kg) } \\
\cline { 2 - 3 } & Jakarta Barat & DKI Jakarta \\
\hline Masker bedah & 122.606 & 498.185 \\
Sarung tangan plastik & 550 & 2.235 \\
Pelindung wajah (face & 111.367 & 452.518 \\
shield) & 2.138 .530 & 8.689 .502 \\
Baju dekontaminasi & $\mathbf{2 . 3 7 3 . 0 5 4}$ & $\mathbf{9 . 6 4 2 . 4 4 1}$ \\
\hline Jumlah &
\end{tabular}

Tabel 7. Rekapitulasi Timbulan Limbah APD di Jakarta Barat

\begin{tabular}{lcc}
\hline \hline \multirow{2}{*}{ Jenis limbah APD } & \multicolumn{2}{c}{ Timbulan (kg/orang/hari) } \\
\cline { 2 - 3 } & Teori & Eksperimen \\
\hline Masker bedah & 0,00153 & 0,165 \\
Sarung tangan & 0,00000642 & 0,00010 \\
Pelindung wajah (face shield) & 0,00141 & 0,145 \\
Baju dekontaminasi & 0,027 & 0 \\
\hline Total limbah APD & 0,03 & 0,17 \\
\hline Sumber: Hasil Pengolahan Data Penelitian 2021
\end{tabular}

Sumber: Hasil Pengolahan Data Penelitian 2021

2. Perhitungan timbulan secara eksperimen adalah perhitungan timbulan sampah yang didasarkan pada proyeksi penduduk tahun 2020 Jakarta Barat dan data jumlah sampah yang berasal dari hasil observasi. Besar limbah APD masker bedah, sarung tangan, pelindung wajah, dan baju dekontaminasi untuk Jakarta Barat secara eksperimen berturut-turut adalah 0,165 $\mathrm{kg}$ /orang/hari, 0,00010 kg/orang/hari, 0,145 $\mathrm{kg}$ /orang/hari, dan $0 \mathrm{~kg} /$ orang/hari. Sehingga, timbulan limbah APD di wilayah Jakarta Barat berdasarkan eksperimen adalah 0,17 $\mathrm{kg} /$ orang/hari.

Berdasarkan perhitungan timbulan limbah APD secara teori dan eksperimen yang telah dilakukan, didapatkan rekapitulasi nilai timbulan di wilayah Jakarta Barat. Rekapitulasi timbulan limbah APD Jakarta Barat dijelaskan pada Tabel 4. Berdasarkan hasil analisis timbulan limbah APD di wilayah Jakarta Barat, didapatkan nilai timbulan eksperimen yang lebih besar dibandingkan teori. Sehingga, data timbulan eksperimen dapat digunakan karena mampu merepresentasikan kondisi timbulan yang sesungguhnya. Perbedaan antara teori dan ekperimen berasal dari asumsi yang diberikan oleh literatur terhadap $30 \%$ warga yang beraktivitas di luar rumah dan menggunakan APD (WIKA, 2020).

\section{- $\quad$ Karakteristik Limbah APD}

Alat pelindung diri (APD) didefinisikan sebagai seperangkat komponen pelindung fisik (physical barrier) yang terdiri dari masker, pelindung wajah (face shield), pelindung mata (googles), sarung tangan, dan baju dekontaminasi (World Health Organization, 2020). Limbah alat pelindung diri (APD) merupakan limbah yang dihasilkan dari pemakaian APD berjenis satu kali pakai (disposable item) maupun beberapa kali pakai (reusable item). Menurut Tabel 4, besar timbulan limbah sekali pakai adalah 97,15\% dan timbulan limbah beberapa kali pakai adalah 2,85\%. Komponen APD yang dapat digunakan kembali (reusable item) seperti face shield, googles, dan baju dekontaminasi, tetap membutuhkan pembaharuan kondisi secara tepat melalui proses desinfeksi atau sterilisasi. Namun, 
proses dekontaminasi tidak berlaku pada masker ataupun jenis respirator lainnya yang memiliki batas pengulangan pemakaian karena akan menghilangkan sifat materi pembangunnya (World Health Organization, 2020). Oleh karena itu, besar timbulan yang dihasilkan pada limbah satu kali pakai akan lebih besar dibandingkan beberapa kali pakai.

\subsection{Bank Sampah Limbah APD}

\section{- Bank Sampah (SIWAB)}

Kesadaran mengelola sampah APD secara tepat belum terwujud secara maksimal di lingkungan masyarakat Jakarta Barat. Hal ini dibuktikan melalui diagram pada Gambar 1 yang menyatakan bahwa sebanyak 55\% responden masyarakat Jakarta Barat masih mencampur limbah APD dengan limbah rumah tangga lainnya. Perilaku ini menyebabkan timbulan limbah APD meningkat di Tempat Pemrosesan Akhir (TPA). Langkah untuk mengurangi tingginya timbulan limbah APD di TPA adalah memilah limbah APD sebagai limbah B3 infeksius yang dapat dimanfaatkan kembali menjadi substitusi bahan baku maupun bahan bakar dalam proses produksi di industri semen (Utami \& Syafrudin, 2018). Smart Infectious Waste Bank (SIWAB) merupakan bank sampah infeksius yang terintegrasi dengan ponsel pintar (smartphone) sehingga memudahkan pengguna dalam menabung sekaligus mengelola limbah APD secara praktis. Inovasi ini memiliki prinsip pemeliharaan lingkungan, peningkatan kualitas kesehatan, dan peningkatan kesejahteraan masyarakat. Melalui SIWAB, nasabah Jakarta Barat bisa menukarkan limbah APD yang dihasilkan dengan uang digital. Aplikasi ini memuat media edukasi masyarakat mengenai pentingnya mengelola limbah APD di rumah masing-masing.

\section{- $\quad$ Alat Angkut}

Penjemputan limbah B3 infeksius di rumah masing-masing masyarakat Jakarta Barat memiliki peran serta dalam mendukung upaya pemerintah membatasi interaksi sosial di tempat umum dan memutus rantai penyebaran infeksi virus COVID-19. Sepeda motor box merupakan angkutan yang disediakan oleh SIWAB untuk memberikan layanan penjemputan limbah APD sebagai limbah B3 infeksius dari setiap lokasi nasabah SIWAB.

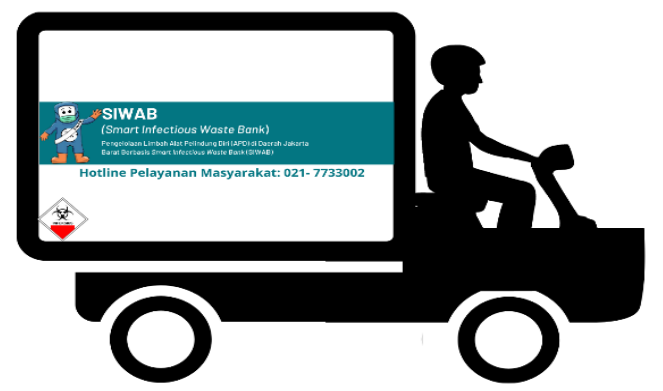

Gambar 2. Desain Alat Angkut SIWAB Sumber: Hasil Pengolahan Data Penelitian 2021
Kendaraan ini merupakan kendaraan tertutup seperti yang dianjurkan dalam Peraturan Pemerintah (PP) No. 22 Tahun 2021, Peraturan Menteri Lingkungan Hidup dan Kehutanan No. 4 Tahun 2020, dan rekomendasi pengangkutan SIWAB yang diterbitkan oleh Kementerian Lingkungan Hidup dan Kehutanan. Selain itu, kendaraan ini dilapisi oleh material yang mampu mencegah kebocoran dari penguapan dan/atau tumpahan limbah B3 ketika sedang diangkut serta mampu menjangkau rumah warga yang memiliki lebar jalan yang kecil sebagai akses kendaraan. Kendaraan ini dilengkapi stiker berupa simbol limbah B3 infeksius pada tiap sisi, identitas SIWAB, dan nomor telepon pelayanan masyarakat. Desain sepeda motor box beserta kelengkapannya, direncanakan seperti pada Gambar 2. Personil yang bertanggung jawab dalam mengangkut limbah APD di tiap rumah dipandu oleh Standar Operasional Prosedur (SOP) SIWAB.

\section{- Tarif Bank Sampah}

Bank sampah SIWAB menetapkan tarif penukaran sampah APD berdasarkan kuantitas lembaran sampah yang dikonversi menjadi berat limbah dan poin penukaran limbah. Poin yang diterima dapat ditukarkan baik ke dalam bentuk uang digital maupun ditukarkan dengan barang ramah lingkungan yang dijual oleh toko daring milik Himpunan Mahasiswa Teknik Lingkungan Universitas Pertamina (HMTL UP). SIWAB berencana bekerja sama dengan perusahaan penyedia uang digital seperti OVO-pay dan GO-pay sehingga nasabah dapat memanfaatkan uang digital untuk keperluan lainnya. Penukaran poin dengan barang ramah lingkungan yang dijual oleh toko daring HMTL UP dapat membantu pengembangan pemasaran produk mahasiswa ke masyarakat umum di Jakarta Barat.

Poin dan uang digital yang diperoleh nasabah akan memiliki perbedaan menurut metode penyerahan limbah ke pihak SIWAB. Jika nasabah melakukan pengantaran limbah APD secara langsung ke Bank Sampah SIWAB, nasabah akan menerima poin yang lebih besar dibandingkan dengan nasabah yang memilih penjemputan limbah APD dengan kendaraan sepeda motor box. Perbedaan tarif tersebut disajikan pada Tabel 8, yang mana memuat besaran poin untuk setiap kilogram limbah APD yang ditukarkan menurut bahan plastik pada limbah dan metode penyerahan limbah kepada bank sampah. Tarif ini merujuk pada Bank Sampah Tuan Di Bagarna (TDB) dengan latar belakang adanya keanekaragaman jenis sampah yang dapat ditukarkan oleh nasabah khususnya jenis sampah berbahan plastik Polipropilena (PP), Polietilena tereftalat (PET), dan Polietilena berdensitas tinggi/High density polietilena (HDPE) (Bank Sampah Tuan Di Bagarna, 2020). Ketiga jenis plastik tersebut merupakan material penyusun limbah APD masker, sarung tangan plastik, pelindung wajah, dan baju dekontaminasi. 
Tabel 8. Tarif Bank Sampah SIWAB

\begin{tabular}{|c|c|c|c|c|c|}
\hline \multirow[b]{2}{*}{ Jenis Limbah } & \multirow[b]{2}{*}{ Kelompok Plastik } & \multicolumn{2}{|c|}{ Poin/Kg (per Kg) } & \multicolumn{2}{|c|}{ Uang Digital/Kg (per Kg) } \\
\hline & & $\begin{array}{l}\text { Dijem - } \\
\text { put }\end{array}$ & Diantar & Dijem-put (Rp) & Dian-tar (Rp) \\
\hline Masker & $\begin{array}{l}\text { Plastik PP (Bening, transparan, } \\
\text { lebih tebal dari PE) }\end{array}$ & 5 & 8 & 500 & 800 \\
\hline Sarung Tangan & $\begin{array}{l}\text { Plastik HDPE (Bening, mudah } \\
\text { ditarik, dan lemas) }\end{array}$ & 45 & 50 & 4.500 & 5.000 \\
\hline Pelindung Wajah & Karah PET (Bening, toples plastik) & 10 & 15 & 1.000 & 1.500 \\
\hline $\begin{array}{c}\text { Baju } \\
\text { Dekontaminasi }\end{array}$ & $\begin{array}{l}\text { Plastik PP (Bening, transparan, dan } \\
\text { lebih tebal dari PE) }\end{array}$ & 5 & 8 & 500 & 800 \\
\hline
\end{tabular}

Sumber: Bank Sampah Tuan Di Bagarna. 2020. Harga Sampah Maret 2020 di Bank Sampah TDB. Pekanbaru

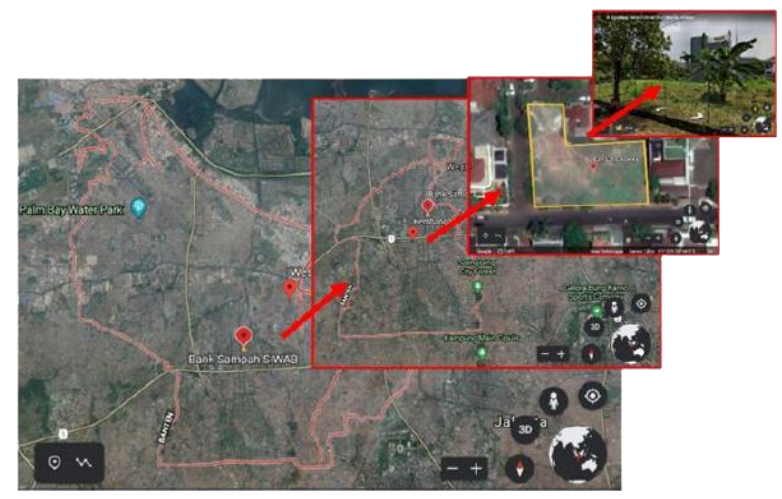

Gambar 3. Lokasi Bank Sampah SIWAB Sumber: Google Earth, 2020

\section{- Lokasi Bank Sampah}

SIWAB memberikan pelayanan bagi masyarakat Jakarta Barat secara daring (online) maupun luring (offline). Bank sampah SIWAB yang melayani secara luring berada di Jalan Kembang Harum Utama No. 1012, RT/RW 005/004, Kembangan Selatan, Kecamatan Kembangan, Jakarta Barat, seperti tertera pada Gambar 3.

Masyarakat dapat melakukan transaksi bank sampah langsung di lokasi ini. Pemilihan lokasi dipertimbangkan dari kemudahan akses lokasi untuk dijangkau oleh masyarakat Jakarta Barat dan timbulan limbah APD dihasilkan paling banyak oleh masyarakat di Kecamatan Kembangan. Petugas bank sampah akan melakukan penimbangan dan verifikasi limbah yang diserahkan. Sistem pencatatan transaksi tabungan bank sampah tersedia secara daring baik pada akun SIWAB maupun pada buku tabungan SIWAB.

\subsection{Aplikasi SIWAB}

SIWAB diperkenalkan sebagai bank sampah yang utamanya bergerak dalam dunia digital. Transformasi dari bentuk konvensional menuju bentuk digital pada bank sampah mampu meningkatkan kenyamanan nasabah dalam menabung limbah APD yang dihasilkan di rumah masing-masing. Nasabah cukup melakukan pemilahan limbah APD sebagai limbah B3 infeksius di rumah masing-masing kemudian melakukan pemesanan layanan penjemputan limbah pada aplikasi SIWAB tanpa dipungut biaya. Mekanisme pelayanan Bank Sampah SIWAB berlangsung dengan melibatkan tiga pihak, yaitu nasabah, aplikasi SIWAB, dan Bank Sampah SIWAB.

Nasabah yang hendak bertransaksi di Bank Sampah SIWAB dapat memulai dengan pengumpulan, pemilahan, dan pengemasan limbah APD. Pengoperasian aplikasi SIWAB dijelaskan melalui Gambar 4. Nasabah membuka aplikasi SIWAB pada smartphone (Nomor 1). Nasabah dapat memulai pengoperasian aplikasi SIWAB dengan mendaftarkan akun terlebih dahulu (register) kemudian masuk ke akun (log in) (Nomor 2). Menu Beranda sebagai tampilan utama dalam aplikasi SIWAB memuat beberapa fitur seperti Dompet SIWAB, Statistik Sampah APD, Smart Education Room, Berita terkait pandemik COVID-19, dan 3 menu untuk memulai transaksi di antaranya adalah menu History, Beranda, dan Pick Up (Nomor 3). Fitur Dompet SIWAB memuat jumlah saldo dan poin yang didapatkan oleh nasabah setelah transaksi pengangkutan limbah APD ke Bank Sampah SIWAB selesai. Fitur Statistik Sampah APD adalah riwayat jumlah limbah APD yang telah nasabah dikirimkan kepada SIWAB. Fitur Smart Education Room adalah fitur untuk mengedukasi masyarakat tentang limbah APD sebagai limbah B3 infeksius, jenis limbah APD, dan panduan mengelola limbah B3 infeksius domestik. 


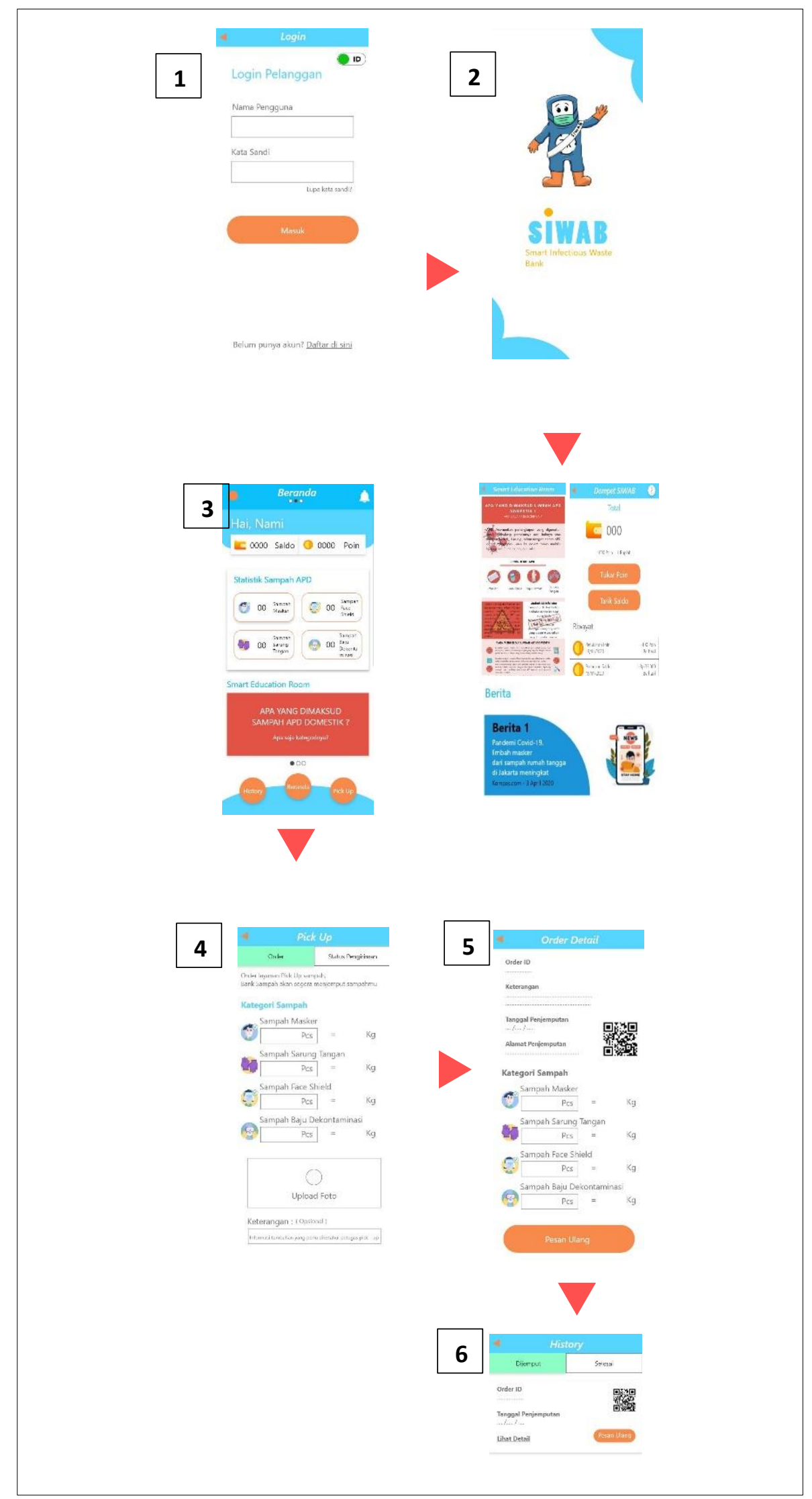

Gambar 4 Panduan Penggunaan Aplikasi SIWAB

Sumber: Hasil Pengolahan Data Penelitian 2021 


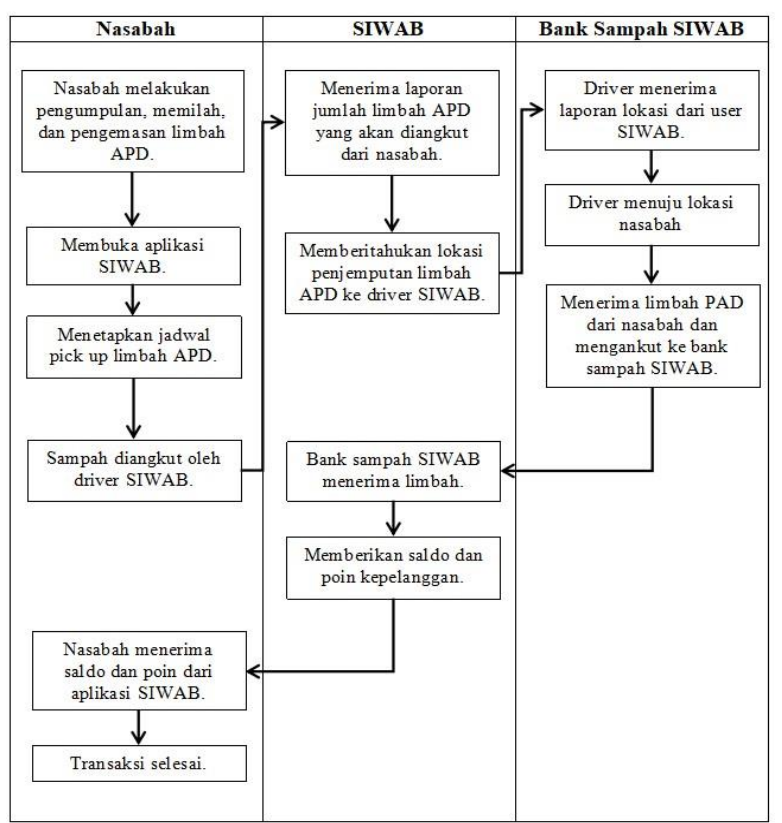

Gambar 5. Skema Mekanisme Layanan Bank Sampah SIWAB

Sumber: Hasil Pengolahan Data Penelitian 2021

Setelah memilah limbah APD sesuai jenisnya (sampah masker, sampah sarung tangan, sampah pelindung wajah/face shield, dan sampah dekontaminasi/hazardous material suit), nasabah dapat menghitung jumlah tiap limbah APD yang kemudian secara otomatis dikonversi oleh aplikasi ke dalam bobot limbah (dalam kilogram) yang dilanjutkan dengan mengunggah foto limbah APD yang hendak diangkut melalui menu Pick Up (Nomor 4). Setelah menguantifikasi bobot limbah APD yang hendak diangkut, nasabah akan dibawa ke menu Order Detail yang memuat salinan konfirmasi pemesanan (Nomor 5). Nasabah bisa menunggu personil/driver SIWAB datang ke rumah untuk mengangkut limbah APD. Jika nasabah ingin melihat kembali salinan bukti pelayanan SIWAB yang telah selesai, nasabah dapat melihat pada menu History pada tab Selesai (Nomor 6).

Mekanisme pelayanan SIWAB dijelaskan melalui Gambar 5. Aplikasi SIWAB yang telah menerima laporan jumlah limbah APD dan lokasi penjemputan limbah APD dari masyarakat segera memberitahukan lokasi penjemputan limbah APD ke driver SIWAB. Setelah itu, driver SIWAB menuju lokasi nasabah, menerima limbah APD, kemudian mengangkutnya ke Bank Sampah SIWAB. Bank Sampah SIWAB yang telah menerima limbah APD dari nasabah memberikan saldo dan poin kepada pelanggan sesuai tarif bank sampah SIWAB. Nasabah menerima saldo dan poin dari aplikasi SIWAB.

\section{Kesimpulan}

Berdasarkan hasil pembahasan tentang Pengelolaan Limbah Alat Pelindung Diri (APD) di
Daerah Jakarta Barat Berbasis Smart Infectious Waste Bank (SIWAB), didapatkan kesimpulan bahwa aplikasi SIWAB merupakan bank sampah yang terintegrasi dengan smartphone sehingga memudahkan pengguna dalam menabung uang sekaligus mengelola limbah APD secara praktis melalui fitur-fitur yang digunakan dalam aplikasi dan diharapkan dapat membantu pemerintah dalam mengelola limbah APD yang dihasilkan oleh kegiatan domestik sekaligus mereduksi timbulan limbah APD di Jakarta Barat.

Dari penelitian ini didapatkan nilai total timbulan limbah APD Jakarta Barat sebesar 0,17 kg/orang/hari. Timbulan limbah APD di Jakarta Barat untuk masker bedah sebesar $0,165 \mathrm{~kg} / \mathrm{orang} / \mathrm{hari}$, sarung tangan sebesar $0,00010 \mathrm{~kg} / \mathrm{orang} / \mathrm{hari}$, pelindung wajah sebesar $0,00485 \mathrm{~kg} / \mathrm{orang} / \mathrm{hari}$, dan baju dekontaminasi sebesar $0 \mathrm{~kg} /$ orang/hari.

\section{DAFTAR PUSTAKA}

Alwi, I. (2016). Kriteria Empirik Dalam Menentukan Ukuran Sampel Pada Pengujian Hipotesis Statistika dan Analisis Butir. Jurnal Formatif, 140-148.

Amazon. (2020, November 22). Personal Protective Equipment. Retrieved from Amazon: https://www.amazon.com

Bank Sampah Tuan Di Bagarna. (2020, November 24). Harga Sampah Maret 2020 di Bank Sampah TDB. Retrieved from Tuan Di Bagarna: https://tdbangarna.com

Bastian, I. W. (2018). Metode Wawancara. Yogyakarta: Universitas Gajah Mada.

BPS. (2015). Proyeksi Penduduk Kabupaten/Kota Provinsi DKI Jakarta 2010-2020. Jakarta: Badan Pusat Statistik Indonesia.

BPS. (2020). Provinsi DKI Jakarta dalam Angka. Jakarta: BPS Provinsi DKI Jakarta.

Detik. (2020, Agustus 12). Ke Mana Sampah APD Jakarta Dibuang? Retrieved from Detik News: https://news.detik.com/berita/d-5129811/kemana-sampah-apd-di-jakarta-dibuang

Dinas Lingkungan Hidup Provinsi DKI Jakarta. (2018). Rencana Strategis 2017-2022 Dinas Lingkungan Hidup Provinsi DKI Jakarta. Jakarta: DInas Lingkunga Hidup Provinsi DKI Jakarta.

Google Earth. (2020, September 11). Citra Satelit Kawasan Kembangan Selatan, Jakarta Barat. Retrieved from Earth Version: https://earth.google.com

Iswanto, Sudarmadji, Wahyuni, E. T., \& Sutomo, A. H. (2016). Timbulan Sampah B3 Rumah Tangga dan Potensi Dampak Kesehatan Lingkungan di Kabupaten Sleman, Yogyayakarta. Jurnal Manusia dan Lingkungan Vol. 23 No.2, 179-188.

Jakarta Smart City. (2020, November 13). Mengolah Limbah Rumah Tangga Melalui Bank Sampah. Retrieved from Jakarta Smart City: https://smartcity.jakarta.go.id/blog/320/mengolahlimbah-rumah-tangga-melalui-bank-sampah

Kementerian Kesehatan Republik Indonesia. (2020). Pedoman Pengelolaan Rumah Sakit Rujukan, Rumah Sakit dan Puskesmas yang Menangani Pasien COVID19. Jakarta: Kementerian Kesehatan Republik Indonesia. 
Keputusan Presiden Republik Indonesia No. 12 Tahun. (2020). Penetapan Bencana Nonalam Penyebaran Corona Virus Disease 2019 (COVID-19) Sebagai Bencana Nasional. Jakarta: Kementerian Sekretarian Negara.

Lee, K.-P. Y.-W.-C.-F. (2020). Reusable Face Masks As Alternatif for Disposable Medical Mask: Factor that Affect their Wear-Comfort. Jurnal Internasionl Environment Reasearch and Public Health, 1-16.

Noviyanti, H. D. (2019). Pengelolaan Sampah di Kota Administrasi Jakarta Barat. Jurnal Seminar Nasional Inovasi Teknologi - SNITek, 195-204.

Pemerintah Kota Administrasi Jakarta Barat. (2020, November 20). Profil Kota Administrasi Jakarta Barat. Retrieved from Kota Administrasi Jakarta Barat: https://www.barat.jakarta.go.id

Ruslinda, Y. \&. (2018). Timbulan, Komposisi, Karakteristik Sampah Berbahaya dan Beracun (B3) pada Sarana Kesehata. Jurnal Dampak, 1-6.

Sarwono, J. (2011). Buku Pintar IBM SPSS Statistics 19. Jakarta: PT. Elex Media Komputindo Kelompok Gramedia.

Setiyono. (2001). Dasar Hukum Pengelolaan Limbah B3. Jurnal Teknologi Lingkungan Vol.2 No.1, 72-77.

Sugiyono. (2012). Memahami Penelitian Kualitatif. Bandung: ALFABETA.

Surat Edaran Menteri Lingkungan Hidup dan Kehutanan No. SE.2/MENLHK/PSLB3/PLB.3/3/2020. (2020). Tentang Pengelolaan Limbah Infeksius (Limbah B3) dan Sampah Rumah Tangga dari Penanganan Corona
Virus DIsease (COVID-19). Jakarta: Kementerian Lingkungan Hidup dan Kehutanan.

Umar, H. (2008). Metode Penelitian untuk Skripsi dan Tesis Bisnis. Jakarta: PT Raja Grafindo Persada.

Utami, K. T., \& Syafrudin. (2018). Pengelolaan Limbah Bahan Berbahaya dan Beracun (B3) Studi Kasus PT. Holcim Indonesia, TBK Narogong Plant. Jurnal Presipitasi: Media Komunikasi dan Pengembangan Teknik Lingkungan Vol.15 No.2, 127-132.

Wain, R. \&. (2020). The Role of Face Shield in Responding to Covid-19. London: Tony Blair Institute For Global Change.

Widoyoko, E. P. (2016). Teknik Penyusunan Instrumen Penelitian. Yogyakarta: Pustaka Pelajar.

WIKA. (2020, November 27). Retrieved from PT. Wijaya Karya (Persero) Tbk: https://www.wika.co.id

World Health Organization. (2020). Rational Use of Personal Protective Equipment for Coronavirus Deases (COVID19) and Consideration During Severe Shortages: Interim Guidance. Geneva: World Health Organization.

Yusup, F. (2018). Uji Validitas dan Reabilitas Instrumen Penelitian Kuantitatif. Jurnal Tarbiyah: Jurnal Ilmiah Kependidikan, 17-23. 